\title{
Validation method of research instruments for Dental Radiology curriculum study
}

\author{
Jeniffer Zettermann da Costa*; Silvany Niemeier Meller*; Linda Behar-Horenstein**; Vania Regina \\ Camargo Fontanella***; Eduardo Galia Reston****; Sergio Augusto Miguens Jr****
}

* Ph.D. Student, School of Dentistry, Universidade Luterana do Brasil

** Ph.D., Professor, Department of Community Dentistry and Behavioral Science, College of Dentistry, University of Florida, Gainesville, USA

*** Ph.D., Associate Professor, Dental School, Universidade Federal do Rio Grande do Sul

Ph.D., Adjunct Professor, Dental School, Universidade Luterana do Brasil

Received September 14, 2017. Approved July 31, 2018.

\begin{abstract}
Dental radiology is an important subject to Dental undergraduate education. Along with other disciplines, it plays a key role in diagnostics, the starting point for patient care. In this way, a specific international guideline for Dental Radiology curriculum was published in 2007. The aim of this study was to develop and validate two distinct instruments, a self-administered online survey, and an interview script, both designed for dental radiology education research. The processes for developing and validating the instruments are described, and the final documents are presented. There were several steps in the validation process of the research instruments in this study, such as translation, cultural adaptation, expert evaluation, read-aloud sessions and pilot testing. This detailed process guarantees control of the variables and helps to avoid bias in regard to the interview and the quantitative/qualitative method analysis.
\end{abstract}

Descriptors: Education. Learning. Radiology. Dentistry. Qualitative Research. Validation Studies. Interview.

\section{INTRODUCTION}

Dental radiology is an important subject to undergraduate dental education. Along with other disciplines, it plays a key role in diagnostics, the starting point for patient care. In 1997, the American Dental Education
Association (ADEA) identified concerns for the quality of dental education and proposed a new curriculum model and related competencies. In 2011, the ADEA House of Delegates updated the Competencies for the New General Dentist guidelines which stated that the undergraduate 
dental curriculum must provide the graduate dentist with the necessary skills for carrying out all activities involving prevention, diagnosis, and treatment of dental patients ${ }^{1,2}$. The graduate dentist is required to develop all major competencies such as professionalism, interpersonal communication and social skills, clinical information gathering, diagnosis and treatment planning, therapy and prevention. The same occurred in Brazil in 2001 through the National Curriculum Guidelines (Diretrizes Nacionais Curriculares, DCN $)^{3}$. In 2007, originating from the International Association of Dentomaxillofacial Radiology (IADMFR) committee in education standards, specific guidelines for Dental Radiology curriculum were published ${ }^{4}$.

Many schools comply with these guidelines; others are still working toward compliance. Educational researchers raise questions about what is being taught, how and by whom. In 2013, a study ${ }^{5}$ suggested that proactive participation, collaboration, and the inclusion of the students in their own educational process was beneficial to their learning. Stimulating critical thinking, eliciting student perceptions and giving adequate feedback to students' questions, along with transparent communication seems to be the direction of higher quality education.

The literature on social science research methods advocates the use of multiple methods, such as self-responded surveys ${ }^{6}$, open-ended surveys $^{7,}$ and interviews ${ }^{5}$; under the conception that qualitative and quantitative methods are complementary rather than rivals. Using both methods simultaneously is one way to strength the power and mitigate the weaknesses found in single method designs. Graduate training usually prepares students to use one method or another as appropriate and preferred, and rarely teaches how to combine methods effectively. Among those who use multiple methods, often they do not explain their technique in sufficient detail to indicate precisely how convergent data are collected and interpreted ${ }^{8}$.

This study aimed to develop and validate two instruments; a self-administered online survey and an interview script, both designed for radiology professors to obtain a profile of the dental radiology education system, to better understand how schools approach teaching required domain and competencies, and to acquire the professors' perceptions of how radiology is taught.

\section{INSTRUMENTS DEVELOPMENT AND VALIDATION PROCESSES}

The process for developing and validating the instruments was accomplished according to figure 1.

For the quantitative instrument, an initial set of 22 items was culled from the literature ${ }^{4}$ and formulated in Portuguese. Questions aimed to identify different domains, competencies, and skills that a future dentist should acquire and then learn more about how curriculum aspects are implemented in the Dental Radiology curriculum. This initial version was discussed and enhanced by eight experts, Dental Radiology professors, in a 3-hour meeting during a Brazilian Dental Radiology conference. The validated version was professionally translated into English.

Upon ethical approval both in Brazil (CAAE: 16031213.4.0000.5349) and the United States (U. S) (IRB 2014-U-0578), the doctoral mentor recruited content experts for the focus group and asked them to assess the readability and clarity of the survey items. An e-mail explaining the purpose of the study was sent to four Dental Radiology faculty members in the U. S. A mutually convenient time was determined, consent for participation was obtained, and then the dissertation mentor moderated a 45-minute 


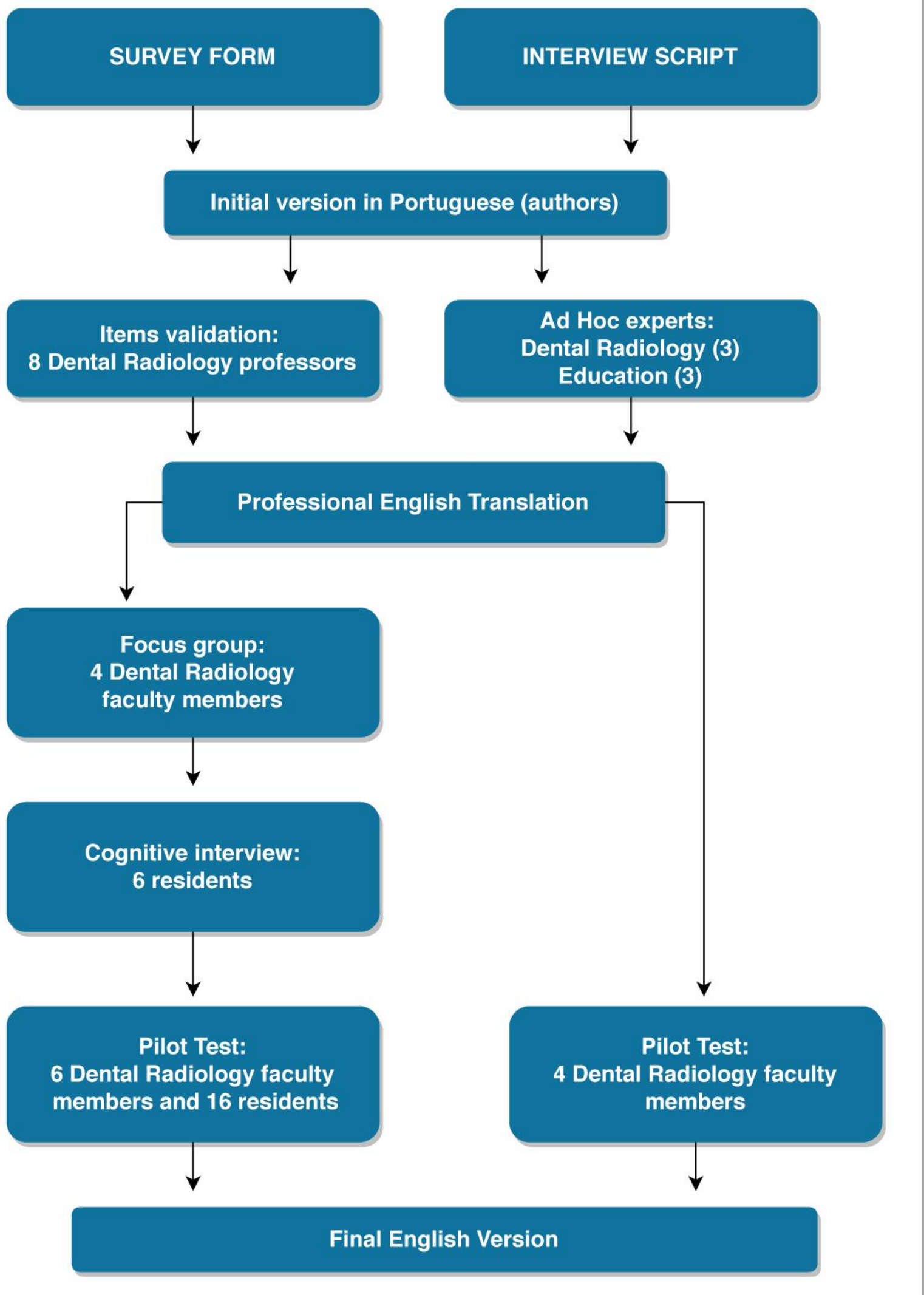

Figure 1. Validation steps of the instruments 
virtual focus group aiming at ensuring that the content of survey was representative of the domain. The questions were read aloud to verify if they were clear and easy to understand and were being interpreted as intended ${ }^{9}$. Each professor offered suggestions that were discussed with the group. Three questions that addressed technologies or practices no longer used in the U. S. were removed. Several survey items were language revised to enhance their clarity.

Next, six residents from the Diagnostics Science Department were invited to participate in a cognitive interviewing. Each of the individuals met independently with the researcher and consent for participation was obtained. They were asked to read aloud the items from the research instrument and explain to the researcher what he or she thinks the item was asking. This process (read-aloud) was undertaken to ensure that each survey item was unambiguous, understandable and that what the respondent thought each question was asking matched the researcher's intent. Consent for participation was obtained. Based on participant feedback from cognitive interviewing, the majority of the questions read well, and only a few survey items were modified for language improvement.

The final step in developing the survey was to conduct a pilot test with six dental faculty members and sixteen residents from the Dental Radiology department who did not participate in the initial focus group nor in the cognitive interview. Using the encrypted and professional version of Survey Monkey, the survey was disseminated to identify item discrimination scores and ensure that items should remain. Following this analysis, all survey items were retained (figure 2).

The qualitative instrument consisted of an interview script and was initially written by the
Brazilian authors in Portuguese. To ensure its content, six Ad Hoc experts in Dental Radiology (3) and Education fields (3) analyzed the questions, that addressed the number of professors who teach radiology curriculum, their qualification and experience, course content and the reading material, teaching methodologies and other resources employed in teaching.

With the aid of input from the experts and after reaching consensus, the interview script was professionally translated into English, and pilot tested with four U.S. Dental Radiology faculty members. The interviews were audio recorded, transcribed and later analyzed by data saturation ${ }^{10-13}$. No changes were made (figure 3 ).

\section{FINAL CONSIDERATIONS}

This paper relies on the importance of describing the validation process for simultaneously using both qualitative and quantitative research instruments ${ }^{14-17}$.

While researching the literature, hardly any studies disclose or even mention the process that led to the development of the survey or investigation instrument that was used ${ }^{5-7,10,18,19}$. Often there is no mention in the articles about the use of these guidelines. Also, very few discuss the validation process and the steps taken $^{20-29}$. Among the studies that do, very little information is given describing how the process was executed ${ }^{30-35}$. This occurs mainly in quantitative studies that utilize surveys, possibly because this design is more widely used and understood than qualitative instruments in health studies.

There were several steps in the validation process of the research instruments in this study, such as translation, cultural adaptation, expert evaluation, read-aloud sessions and pilot testing. This detailed process guaranteed control 
Validation method of research instruments for Dental Radiology curriculum study



Figure 2. Validated survey form 


\section{INTERVIEW SCRIPT}

Part 1 - Data Training / manning / teaching function

The institution where studied (graduation). In what year have he/she graduated? What is your academic background? How long have you taught? Disciplines? Semesters? Have an administrative role in the course or college?

Part 2 - General questions "to teach college"

For you what is to be a university teacher? What are the roles of the teacher?

Are you involved in, or conducts research and extension activities at the university?

\# If yes: What are they? (interdisciplinary / inter-institutional). What is the workload? How are they developed?

\# If not: Is there any special reason for not participating?

Part 3 - Issues on curricular "teaching / teaching radiology"

Which model curriculum of your course? (modular, annual / semi-annual, per subject)

You exert some educational function or is involved with the pedagogical design of the course?

Did you participate in the development / implementation of the current curriculum model in your school?

Are you satisfied or like to teach this model?

\# If yes: Why? What are the positives / strengths?

\# If not: Why? What are the negatives / weaknesses?

What do you think should change? content, form)

Are you satisfied with the contents?

\# If not: What would you like to teach? What do you think should stay in the undergraduate curriculum and the content that should be graduate?

At what point or at what time the curriculum content is located in dental radiology?

Do you think are appropriate?

\# If not: How do you think would be better?

Are there separate lectures and preclinical or clinical activities specific for teaching the content of dental radiology practices? specify

Part 4 - Questions " skills and abilities " for teaching dental radiology

Taking into account the skills that should be part of the student's education (examples: healthcare, lifelong learning, decision making and communication), which you think are essential in the development of the discipline of radiology? Are pupils in patient care? (execution of techniques, radiographic examinations, delivery of reports).

\# If yes: They are trained / trained for this? How? Are students instructed / trained to indicate the techniques to be performed on these patients or are pre-established by the discipline? Check if the reported techniques are covered in the syllabus

The students prepare diagnoses (or radiographic reports)? How?

Which model of teaching radiographic techniques? Specify type(s). Which radiographic techniques are taught?

In which radiographic techniques students must have skills (essential)? Are radioprotection protocols used?

Which courseware is used as a reference discipline? Is the material produced by the discipline? What are the basic references to the subject?

And further? The students are encouraged to read scientific articles, books or other supplementary materials to class? Are the students encouraged to read materials in other languages? What? The course works with seminars or resolution of cases (PBL)?

The content of radiology is inserted into other disciplines?

\# If yes: What content - and what disciplines? Who provides radiologists are teachers? There is a philosophical conflict with other disciplines?

The course offers training, boarding, training or technical training for diagnostic imaging?

\# If yes: For what audience?

Is there any extension activity for students in radiology? (projects, programs, courses, service)

Part 5 - Issues of assessment and perception of academic learning

Monitoring or assessment of student learning at the end of the course that was taught in the subject (s) of radiology?

\# If yes: How? \# If not: What is your opinion about it?

In your opinion, the student after the course has appropriate skills in performing techniques and radiographic diagnosis?

Part 6 - Issues - other issues (additional collaboration to the interview)

Besides the issues discussed, you would like to make any additional comments?

End of the interview, thank the participation and collaboration

Note: Sending the plan of instruction at the end of the interview.

Figure 3. Validated interview script 
of the variables and also permitted that any bias was minimized in regard to the interview and the quantitative/qualitative method analysis.

\section{RESUMO}

Método de validação de instrumentos de pesquisa para estudo do currículo de Radiologia Odontológica

A Radiologia Odontológica é um conteúdo curricular importante para a graduação em Odontologia, pois juntamente com outras disciplinas desempenha um papel fundamental no diagnóstico, ponto de partida para o atendimento ao paciente. Desta forma, uma diretriz internacional específica para o currículo de Radiologia Odontológica foi publicada em 2007. O objetivo deste estudo foi desenvolver e validar dois instrumentos distintos, uma pesquisa online auto administrada e um roteiro de entrevista, ambos projetados para a pesquisa de educação em Radiologia Odontológica. Os processos de desenvolvimento e de validação dos instrumentos são descritos e os documentos finais são apresentados. Houve várias etapas no processo de validação dos instrumentos de pesquisa deste estudo, como tradução, adaptação cultural, avaliação de especialistas, sessões de leitura em voz alta e testes piloto. Esse processo detalhado garante o controle das variáveis e ajuda a evitar vieses em relação à entrevista e à análise do método quantitativo/qualitativo.

Descritores: Educação. Ensino. Radiologia. Odontologia. Pesquisa Qualitativa. Estudos de Validação. Entrevista.

Acknowledgment: Authors acknowledge the Coordenação de Aperfeiçoamento de Pessoal de Ensino Superior/CAPES for funding this study.

\section{REFERENCES}

1. ADEA Competencies for the new General Dentist. J Dent Educ. 2011;75(7): 932-5.

2. ADEA House of Delegates Manual 2011. ADEA Resolution 11H-2011. 2011;86-92.

3. Brasil. Ministério da Educação. Conselho Nacional de Educação. Câmara de Educação
Superior. Resolução CNE-CES 3, de 19/02/2002 Institui as Diretrizes Curriculares Nacionais do Curso de Graduação em Odontologia. Diário Oficial. 2002;1:(10).

4. IADMFR Education Standards Committee. Undergraduate dental education in dental and maxillofacial radiology. Dentomaxillofac Radiol. 2007;36:443-50.

5. Subramanian J, Anderson VR, Morgaine KC, Thomson WM. Effective and ineffective supervision in postgraduate dental education: a qualitative study. Eur J Dent Educ. 2013;17:e142-e150.

6. Du GF, Li CZ, Shang SH, Xu XY, Chen HZ, Zhou G. Practising case-based learning in oral medicine for dental students in China. Eur J Dent Educ. 2013;17:225-8.

7. Jahangiri L, McAndrew M, Muzaffar A, Mucciolo W. Characteristics of effective clinical teachers identified by dental students: a qualitative study. Eur J Dent Educ. 2013;17:10-8.

8. Jick TD. Mixing qualitative and quantitative methods: triangulation in action. Admin Sci Quart. 1979;24:602-611.

9. Behar-Horenstein L, Leite W. The StudentCentered Teachers' Beliefs Survey: an initial validity study based on a unified latent variable framework. Curric Teaching. 2011;26(1):57-72.

10. Toassi RFC, Stobäus CD, Mosquera JJM, Moysés SJ. Integrated curriculum for teaching dentistry: new directions for training in the field of healthcare. Interface. 2012;16(41):529-42.

11. Fontanella BJB, Ricas J, Turato ER. Saturation sampling in qualitative health research: theoretical contributions. Cad Saúde Pública. 2008;24:17-27.

12. Turato ER. Qualitative and quantitative methods in health: definitions, differences 
and research subjects. Rev Saúde Pública. 2005;39(3):507-14.

13. Coyne IT. Sampling in qualitative research. Purposeful and theoretical sampling; merging or clear boundaries? J Adv Nurs. 1997;26:623-30.

14. MacNeally MS. Strategies for Empirical Research in Writing. London, UK: Longman; 1998.

15. Patton M. Qualitative Research \& Evaluation Methods. Thousand Oaks, CA: Sage Publications, Inc; 2002.

16. Tong A, Sainsbury P, Craig J. Consolidated Criteria for Reporting Qualitative Research (COREQ): a 32-item checklist for interviews and focus groups. Int $\mathrm{J}$ Qual Health Care. 2007;19(6):349-57.

17. O’Brien BC, Harris IB, Beckman TJ, Reed DA, Cook DA. Standards for reporting qualitative research: a synthesis of recommendations. Acad Med. 2014;89(9):1245-51.

18. Bush HM, Schreiber RS, Oliver SJ. Failing to fail: clinicians' experience of assessing underperforming Dental students. Eur J Dent Educ. 2013;17:198-207.

19. Bengmark D, Nilner M, Rohlin M. Dentists reflect on their problem-based education and professional satisfaction. Eur J Dent Educ. 2012;16:e137-e145.

20. Jonas-Dwyer DRD, Abbott PV, Boyd N. First reflections: third-year dentistry students' introduction to reflective practice. Eur J Dent Educ. 2013; 17:e64-e69.

21. Bullock A, Bailey S, Cowpe J, Barnes E, Thomas H, Thomas R, et al. Continuing professional development systems and requirements for graduate dentists in the EU: survey results from the DentCPD project. Eur J Dent Educ. 2013;17(Suppl.1):18-22.

22. Sabounchi SS, Nouri M, Erfani N, Houshmand B, Khoshnevisan MH.
Knowledge and attitude of dental faculty members towards evidence-based dentistry in Iran. Eur J Dent Educ. 2013;17:127-37.

23. Scheven BAA. Perceived relevance of oral biology by dental students. Eur J Dent Educ. 2012;16:e64-e72.

24. Atashrazm P, Vallaie N, Rahnema R, Ansari H, Pour Shahab M. Worldwide Predoctoral Dental Implant Curriculum Survey. J Dent (Tehran). 2018(1):12-8.

25. Licari FW, Chambers DW. Some paradoxes in Competency-Based Dental education. J Dent Educ. 2008;72(1):8-18.

26. Cardall WR, Rowan RC, Bay C. Dental Education from the Students' perspective: curriculum and climate. J Dent Educ. 2008;72(5):600-9.

27. Haghparast N, Sedghizadeh PP, Shuler CF, Ferati D, Christersson C. Evaluation of student and faculty perceptions of the PBL curriculum at two dental schools from a student perspective: a cross-sectional survey. Eur J Dent Educ. 2007;11:14-22.

28. Henzi D, Davis E, Jasinevicius R, Hendricson W. North American Dental students' perspectives about their clinical education. J Dent Educ. 2006;70(4):361-77.

29. Kantor ML. Longitudinal trends in the use of individualized radiographic examinations at Dental Schools in the United States and Canada. J Dent Educ. 2006;70(2):160-8.

30. Brumini G, Spalj S, Mavrinac M, BiocinaLukenda D, Strujic M, Brumini M. Attitudes towards e-learning amongst dental students at the universities in Croatia. Eur J Dent Educ. 2014;18:15-23.

31. Fazel A, Jafari A, Khami MR, Seddighpour L, Kharrazifard MJ, NassibiM, et al. Dental Curriculum Revision in Iran: Dentists' Perspective on Achievement of Essential Competencies through National Curriculum. Iranian J Publ Health. 2013;42(1):129-33. 
32. Manakil J, George R. Self-perceived work preparedness of the graduating dental students. Eur J Dent Educ. 2013;17:101-5.

33. Ruprecht A. The status of oral and maxillofacial radiology worldwide in 2007. Dentomaxillofac Radiol. 2009;38:98-103.

34. Thammasitboon K, Sukotjo C, Howell H, Karimbux N. Problem-Based Learning at the Harvard School of Dental Medicine: selfassessment of performance in postdoctoral training. J Dent Educ. 2007;71(8):1080-9.

35. Kantor ML, Schneider D, O'Caroll MK. Attributes and practices of oral and maxillofacial radiology departments in US and Canadian Dental Schools. Oral Surg Oral Med Oral Pathol Oral Radiol Endod. 2001;91:101-8.
Correspondence to:

Sergio Augusto Quevedo Miguens Jr e-mail: samiguens@ gmail.com Av. Farroupilha, 8001 São José 92425-900 Canoas/RS Brazil 